\title{
First record of Solmundella bitentaculata (Cnidaria: Aeginidae) in Pará State Shelf, Brazil
}

\author{
T. N. S. Banha ${ }^{a}$, S. N. Stampar ${ }^{b}$ and J. E. Martinelli-Filho ${ }^{c, d}$ \\ aPrograma de Pós-graduação em Oceanografia, Instituto Oceanográfico, Universidade de São Paulo - USP, \\ Praça do Oceanográfico, 191, sala 139, CEP 05508-120, São Paulo, SP, Brazil \\ 'Laboratório de Evolução e Diversidade Aquática, Departamento de Ciências Biológicas, Faculdade de Ciências e Letras \\ de Assis, Universidade Estadual Paulista - UNESP, Av. Dom Antônio, 2100, CEP 19806-900, Assis, SP, Brazil \\ 'Laboratório de Oceanografia Biológica - LOB, Instituto de Geociências, Universidade Federal do Pará - UFPA, \\ Rua Augusto Corrêa, 01, Campus Guamá, CEP 66075-110, Belém, PA, Brazil \\ ${ }^{d}$ Laboratório de Pesquisa em Monitoramento Ambiental Marinho - LAPMAR, Instituto de Geociências, \\ Universidade Federal do Pará - UFPA, Rua Augusto Corrêa, 01, Campus Guamá, CEP 66075-110, Belém, PA, Brazil \\ *e-mail: oc.tnsb@gmail.com; sotobanha@usp.br
}

Received: July 06, 2016 - Accepted: August 16, 2016 - Distributed: February 28, 2018

(With 1 figure)

\section{Introduction}

Solmundella bitentaculata (Quoy and Gaimard, 1833) was first described by Quoy and Gaimard (1833) as Charybdea bitentaculata and subsequently as Aeginella bitentaculata by Haeckel, 1879. Unlike other jellyfish, S. bitentaculata swims using its two tentacles held in the top of the umbrella, the main characteristic of this species. The life cycle is holoplanktonic, although reproduction remains unknown (Bouillon, 1999). The species is cosmopolitan, found at different environmental conditions, depths and latitudes (Kramp, 1961).

The Amazon River plume influences a huge area of the shelf, and may be a barrier to marine planktonic species. Therefore, the objective of this paper is to establish the first record of $S$. bitentaculata in the Pará State coast, contributing to the knowledge on pelagic invertebrates at the Brazilian North region.

\section{Material and Methods}

The sample containing Solmundella bitentaculata was collected $52.5 \mathrm{~km}$ far from Pará's coast, $\left(0^{\circ} 01\right.$ ' $0.6^{\prime} \mathrm{N}$, 47 57'48.4'W), on April, 2013, by oblique trawling along the water column, from the bottom to the surface, using a $200 \mu \mathrm{m}$ cylindrical-conical plankton net. The water average temperature was $29^{\circ} \mathrm{C}$, salinity 19.7 and maximum depth of 16 meters. The sample was fixed by $4 \%$ seawater formaldehyde solution buffered with sodium tetraborate. In the laboratory, size measurements were made with a stereomicroscope and identification was based on Quoy and Gaimard (1833) and Bouillon (1999).

\section{Results}

One mature specimen was collected (Figure 1), from the Pará state Continental Shelf and it was deposited at Museu Parense Emilío Goeldi (MPEG 001). It has an umbrella with $2.12 \mathrm{~mm}$ width and $1.66 \mathrm{~mm}$ length, tentacles with $9.75 \mathrm{~mm}$ length and a wide stomach with rectangular pouches. Apical exumbrella very thick with two long opposite tentacles starting near to the top of the umbrella, ending far from the bell, without secondary tentacles. The specimen has also two tentacular peronia and 8 statocysts.

\section{Discussion}

The reduced number of published studies on gelatinous plankton at the Amazon may be explained by the lack of specialists in the region and by the influence of the Amazon River plume, generating a saline barrier along the Pará and Amapá states coast, mainly after the rainy season (Molleri et al., 2010; Bernardes et al., 2012).

The role of Amazon plume in the biogeography of planktonic community was reported recently (Goes et al., 2014) and the absence of $S$. bitentaculata in other regions of the Amazon coast (e.g. Mesquita et al., 2006) might be an evidence that river plume may limit the density and distribution of the oceanic taxa.

Several records of the species were reviewed to the Brazilian coast (Migotto et al., 2002), including Southeast (Vannucci, 1957; Silveira and Morandini, 2011) and Northeast coasts (Goy, 1979; Gusmão et al., 2015). However, the record of $S$. bitentaculata to the North coast was published during the 1960's (Alvariño, 1968), described between off Amapá State and French Guiana. Unfortunately, the author did not provide coordinates to the sampling stations where $S$. bitentaculata specimens were found, just a density estimates contour map. Therefore, this record may be the first to Brazilian Northern coast, if such specimens were collected at French Guiana shelf.

Vannucci (1957) found 27 specimens in the coast of São Paulo state on the surface and depths of 10, 30 and 60 meters and mean temperature and salinity of $21.99^{\circ} \mathrm{C}$ and 35.88, respectively. Gusmão et al. (2015) sampled a mean density of 24 ind. $\mathrm{m}^{-3}$ in only one oceanic sample, considering the species rarely distributed. Environmental 


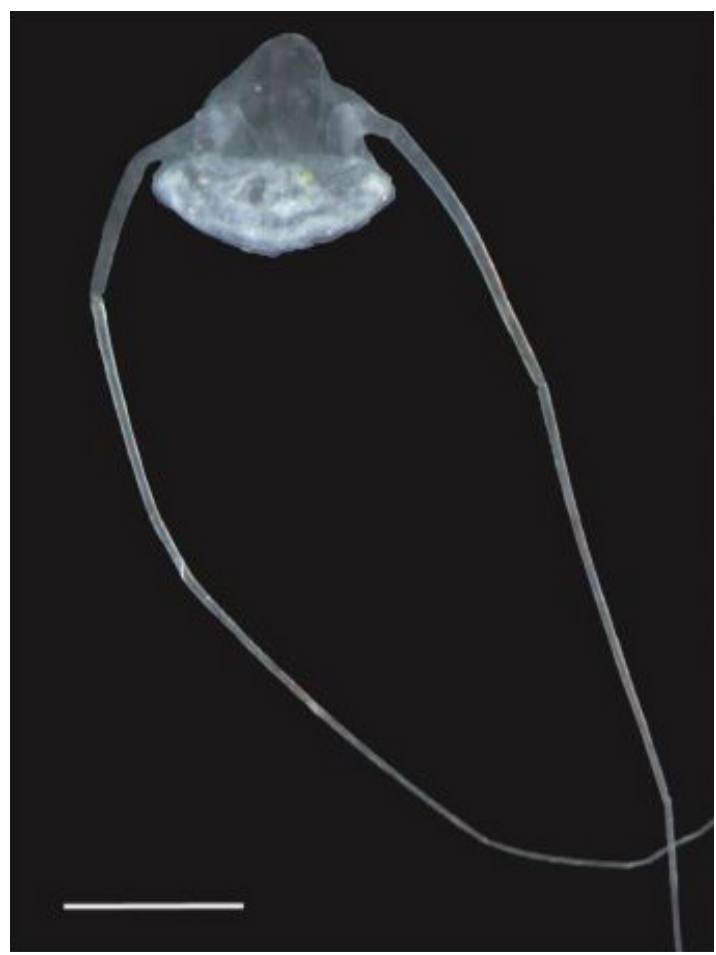

Figure 1. The collected specimen of Solmundella bitentaculata (Quoy and Gairmard, 1833). Scale bar, $2 \mathrm{~mm}$.

information and scarcity of the species in the sample points seems to be consonant with the data of previous researches along Brazilian coast.

Therefore, despite the low salinity, oceanic taxa may be detected as $S$. bitentaculata. These taxa contribute to the existence of a unique environment, the Amazonia and Guianian marine ecoregions (Spalding et al., 2007), clearly distinguished by influence of the river and its role on biodiversity's structure. However, it is still necessary molecular data to differ the South America northern populations. Thus, this record is an important contribution to future studies on gelatinous zooplankton in this area.

\section{Acknowledgements}

We thank MSc. Rosângela Souza and Dr. Eduardo Paes for collect and provide the organisms to the authors and BSc. Mariana de Andrade for helping editing the image used on the paper. This work was partly supported by São Paulo Research Foundation (FAPESP 2015/24408-4) to SNS and Federal University of Pará (UFPA/FADESP $\left.\mathrm{n}^{\circ} 09 / 2014\right)$ to JEMF.

\section{References}

ALVARIÑO, A., 1968. Los quetognatos, sifonóforos y medusas en la región del Atlántico Ecuatorial bajo la influencia del Amazonas. Anales del Instituto de Biología, Universidad Nacional Autónoma de México. Serie Ciencias del Mar y Limnologia, vol. 39, no. 1, pp. 1-76.
BERNARDES, M.C., KNOPPERS, B.A., REZENDE, C.E., SOUZA, W.F.L. and OVALLE, A.R.C., 2012. Land-sea interface features of four estuaries on the South America Atlantic coast. Brazilian Journal of Biology $=$ Revista Brasileira de Biologia, vol. 72, no. 3, suppl., pp. 761-774. PMid:23011302. http://dx.doi. org/10.1590/S1519-69842012000400011.

BOUILLON, J., 1999. Hydromedusae. In: D. BOLTOVSKY, ed. South Atlantic Zooplankton. Leiden, Netherlands: Bachuys Publishers, pp. 385-465.

GOES, J.I., GOMES, H.R., CHEKALYUK, A.M., CARPENTER, E.J., MONTOYA, J.P., COLES, V.J., YAGER, P.L., BERELSON, W.M., CAPONE, D.G., FOSTER, R.A., STEINBERG, D.K., SUBRAMANIAM, A. and HAFEZ, M.A., 2014. Influence of the Amazon River discharge on the biogeography of phytoplankton communities in the western tropical north Atlantic. Progress in Oceanography, vol. 120, pp. 29-40. http://dx.doi.org/10.1016/j. pocean.2013.07.010.

GOY, J., 1979. Campagne de la Calypso au large des côtes atlantiques de l'Amérique du sud (1961-1962)-35. Méduses. Résultats Scientifiques des Campagnes de la Calypso, vol. 11, pp. 263-296.

GUSMÃO, L.M.O., DIAZ, X.F.G., MELO, M., SCHWAMBORN, R. and NEUMANN-LEITÃO, S., 2015. Jellyfish diversity and distribution patterns in the tropical Southwestern Atlantic. Marine Ecology, vol. 36, no. 1, pp. 93-103. http://dx.doi.org/10.1111/ maec.12119.

KRAMP, P.L., 1961. Synopsis of the medusae of the world. Journal of the Marine Biological Association of the United Kingdom, vol. 40, pp. 469. http://dx.doi.org/10.1017/S0025315400007347.

MESQUITA, S.S.A., COSTA, R.M., PEREIRA, L.C.C. and MAGALHÃES, A., 2006. Composição, ocorrência e distribuição das hidromedusas no estuário do rio Caeté, litoral do estado do Pará. Boletim do Museu Paraense Emílio Goeldi, vol. 1, no. 3, pp. 113-119.

MIGOTTO, A.E., MARQUES, A.C., MORANDINI, A.C. and SILVEIRA, F.L., 2002. Checklist of the Cnidaria Medusozoa of Brazil. Biota Neotropica, vol. 2, no. 1, pp. 1-31. http://dx.doi. org/10.1590/S1676-06032002000100010.

MOLLERI, G., NOVO, E.M.L.M. and KAMPEL, M., 2010. Space-time variability of the Amazon River plume based on satellite ocean color. Continental Shelf Research, vol. 30, no. 3-4, pp. 342-352. http://dx.doi.org/10.1016/j.csr.2009.11.015.

QUOY, J.R.C. and GAIMARD, J.P., 1833. Zoologie IV: Zoophytes. In: M.J.D. D'URVILLE. Zoologie. Voyage de la corvette l'Astrolabe: exécuté par ordre du roi, pendant les années 1826-1827-18281829. Paris: J. Tastu. pp. 1-390.

SILVEIRA, F.L. and MORANDINI, A.C., 2011. Checklist dos Cnidaria do Estado de São Paulo, Brasil. Biota Neotropica, vol. 11, no. 1, pp. 445-454. http://dx.doi.org/10.1590/S167606032011000500016 .

SPALDING, M.D., FOX, H.E., ALLEN, G.R., DAVIDSON, N., FINLAYSON, M., HALPERN, B.S., JORGE, M.A., LOMBANA, A., LOURIE, S.A., MARTIN, K.D., MOLNAR, J., RECCHIA, C.A. and ROBERTSON, J., 2007. Marine ecoregions of the world: a bioregionalization of coastal and shelf areas. Bioscience, vol. 57, no. 7, pp. 573-583. http://dx.doi.org/10.1641/B570707.

VANNUCCI, M., 1957. On Brazilian hydromedusae and their distribution in relation to different water masses. Boletim do Instituto Oceanográfico, vol. 8, no. 1-2, pp. 23-109. http://dx.doi. org/10.1590/S0373-55241957000100002. 